\title{
Molecular phylogenetic analysis of Pulmonata (Mollusca: Gastropoda) on the basis of Histone-3 gene
}

\author{
Vijaya Sai Ayyagari®i and Krupanidhi Sreerama*
}

\begin{abstract}
Background: In the present study, phylogenetic relationships within Heterobranchia in particular to Pulmonata were evaluated by means of Histone-3 $(\mathrm{H} 3)$ gene sequence information. $\mathrm{H} 3$ gene is a slow evolving marker and is useful in resolving the deep level relationships. This is the first study to report the phylogeny of Pulmonata with more number of representatives from the group on the basis of $\mathrm{H} 3$ gene.

Results: The major groups within Heterobranchia viz. Lower Heterobranchia, Opisthobranchia, and Pulmonata were non-monophyletic. A few of the pulmonate groups' viz. Planorbidae, Lymnaeidae, Siphonariidae, Veronicellidae, and Stylommatophora were recovered as monophyletic. The concepts of Eupulmonata and Geophila were not observed in the present study.

Conclusions: The present study was undertaken with an objective to study the phylogeny of Pulmonata reconstructed on the basis of $\mathrm{H} 3$ gene and its ability to resolve the deeper divergences in Pulmonata. However, the resolution at the deeper nodes is limited. There is a good resolution at the level of genera. In the future, inclusion of more number of taxa with increased sequence length of $\mathrm{H} 3$ marker may yield resolved topologies that may shed more insights into the phylogeny of Pulmonata.
\end{abstract}

Keywords: Gastropoda, Histone-3 gene, Phylogeny, Heterobranchia, Pulmonata

\section{Background}

Heterobranchia [1] is divided into Allogastropoda (=Lower Heterobranchia) and Euthyneura. The former is characterized by the presence of "Tri-ganglionate" state and the later (Euthyneura) by the "Penta-ganglionate" state by the acquisition of a pair of "Parietal ganglia" [1,2]. The word "Euthyneura" was coined by Spengel [3] for uniting the taxa that reverted from the crossed state of visceral loop to uncross state during the process of detorsion. However, this is not considered as a synapomorphic character for "Euthyneura" due to the presence of this condition in few "Streptonerous" taxa [1]. Euthyneura is further divided into Opisthobranchia and Pulmonata. Each of these two groups is distinct on the basis of several synapomorphic characters of the nervous system [2]. Despite these synapomorphic characters, different molecular phylogenetic studies have yielded Lower

\footnotetext{
* Correspondence: krupanidhi.srirama@gmail.com

Department of Biotechnology, Vignan's Foundation for Science, Technology \& Research (Deemed to be University), Vadlamudi, Andhra Pradesh 522 213, India
}

(c) The Author(s). 2019 Open Access This article is distributed under the terms of the Creative Commons Attribution 4.0 International License (http://creativecommons.org/licenses/by/4.0/), which permits unrestricted use, distribution, and reproduction in any medium, provided you give appropriate credit to the original author(s) and the source, provide a link to the Creative Commons license, and indicate if changes were made.
Heterobranchia, Euthyneura, and Pulmonata as nonmonophyletic [4-10].

Over the past few decades, with the advent of molecular techniques, there is growing information available with regard to the phylogenetic affinities among different groups of gastropods by means of widely used mitochondrial $(16 \mathrm{~S}, \mathrm{COI})$ and nuclear molecular markers $(18 \mathrm{~S}, 28 \mathrm{~S})$ in reconstructing their phylogenetic affinities. However, there is a need for new nuclear markers in studying gastropodan phylogenies especially with regard to deeper divergences. Histone-3 (H3) protein is one among the four highly conserved core nucleosome proteins that associate with DNA [11]. H3 gene, a nuclear marker is slow evolving when compared to the fast evolving mitochondrial markers like $16 \mathrm{~S}$ and COI. Therefore, $\mathrm{H} 3$ gene is useful in studying the deep level relationships (for obtaining resolution at deeper nodes), while the widely used mitochondrial markers $(16 \mathrm{~S}, \mathrm{COI})$ are useful in resolving the relationships at the level of genera (Dinapoli et al. [12]). Colgan et al. [13] first used \\ SpringerOpen}


H3 marker for studying the phylogenetic relationships among Arthropoda along with U2 snRNA gene.

With regard to the utility of $\mathrm{H} 3$ gene in the phylogenetics of Gastropoda, it was used either alone [12] or in combination with different molecular markers [14, 15]. In all these studies, taxa from Pulmonata were poorly represented. Further, there are no comprehensive phylogenetic studies available on Pulmonata on the basis of $\mathrm{H} 3$ gene or in combination with other molecular makers to date. Hence, the objective of the present study is to evaluate the phylogenetic affinities among different groups of Pulmonata by including more number of sequences available for major pulmonate groups from GenBank along with the sequences obtained from the present study by means of $\mathrm{H} 3$ sequence information. The present work is also carried out with a view to evaluate the utility of this marker to understand the phylogeny of Pulmonata, especially with regard to divergence of internal nodes.

\section{Methods}

\subsection{Collection of specimens}

Three different species of pulmonate gastropods viz., Laevicaulis alte, Gyraulus convexiusculus, and Lymnaea (Pseudosuccinea) acuminata form rufescens were collected for the present study. Laevicaulis alte was collected from the Selapadu village from the state of Andhra Pradesh, India. Gyraulus convexiusculus and Lymnaea (Pseudosuccinea) acuminata form rufescens were collected from the "Ganesha" pond located at Sri Sathya Sai Prasanthi Nilayam Ashram, Andhra Pradesh, India. All the three specimens were sent to the Zoological Survey of India, Kolkata, for their identification.

\subsection{Isolation of genomic DNA, PCR, and sequencing of H3 gene}

The genomic DNA was isolated from the foot muscle tissue of snails using NucleoSpin ${ }^{\circ}$ Tissue kit (MachereyNagel) by following the manufacturer's instructions.

$\mathrm{H} 3$, a nuclear protein coding gene, was amplified using the primers H3F-ATGGCTCGTACCAAGCAGACVGC and H3R- ATATCCTTRGGCATRATRGTGAC [14]. The three species of gastropods were so far not sequenced for $\mathrm{H} 3$ gene and the analyzed sequences of these three taxa were deposited for the first time to the National Centre for Biotechnology Information (NCBI) and DNA Databank of Japan (DDBJ). Apart from these, a few more sequences were retrieved from NCBI GenBank and were included in the present study (Table 1).

PCR was carried out in a final volume of $20 \mu \mathrm{l}$ with $1 \mathrm{X}$ Phire PCR buffer (contains $1.5 \mathrm{mM} \mathrm{MgCl}_{2}$ ), $0.2 \mathrm{mM}$ dNTPs, $0.25 \mu \mathrm{M}$ forward and reverse primers, $0.2 \mathrm{U}$ Phire hot start II DNA polymerase, $0.15 \mathrm{mg} / \mathrm{ml}$ BSA, 3\% DMSO, $0.5 \mathrm{M}$ Betaine, $1 \mu \mathrm{l}$ genomic DNA, and the final volume was adjusted to $20 \mu \mathrm{l}$ using molecular biology grade water. PCR amplification was performed in a thermal cycler (GeneAmp PCR system 9700, Applied Biosystems) with the following amplification profile: denaturation at $98^{\circ} \mathrm{C}$ for $30 \mathrm{~s}$ followed by 40 cycles of denaturation at $98^{\circ} \mathrm{C}$ for $5 \mathrm{~s}$, annealing at $54^{\circ} \mathrm{C}$ for $10 \mathrm{~s}$, extension at $72{ }^{\circ} \mathrm{C}$ for $15 \mathrm{~s}$ followed by final extension at $72{ }^{\circ} \mathrm{C}$ for $60 \mathrm{~s}$.

PCR products were purified using ExoSAP-IT ${ }^{\mathrm{ma}}$ (GE Healthcare) following the manufacturer's instructions and were sequenced using the same primers that were used for PCR at the Regional Facility for DNA Fingerprinting, Thiruvananthapuram, India.

The obtained chromatograms were visualized and necessary editing process was carried out in DNA Baser v4.20.0 [16] for obtaining consensus sequences. The sequences thus obtained were searched against the BLAST program of NCBI to check for contamination and subsequently submitted to DDBJ and NCBI GenBank and were assigned the following accession numbers LC198673, KX514447 - KX514448.

\subsection{Multiple sequence alignment}

Nucleotide sequences retrieved from GenBank were verified whether they were amplified by the same set of primers used in the present study or from the same regions of Histone 3 gene. After confirmation, nucleotide sequences obtained in the present study as well as those retrieved from NCBI GenBank (for few sequences) were trimmed at $5^{\prime}$ end in order to bring the sequences into reading frame. This ensures that stop codons are not present after the translation of nucleotide sequences to amino acids. Non-coding nucleotides were also removed from the 3 '-end. Further, sequences obtained in the present study as well as those retrieved from NCBI GenBank were reverse complemented wherever the gene was in the complement (minus) strand.

Multiple sequence alignment was performed in MEGA v6.06 [17] using the inbuilt muscle program [18] with default parameters. Alignment of nucleotide sequences was guided by the translated amino acids. Regions of ambiguous alignments were excluded using online Gblocks server [19] under "less stringent" and "more stringent" options.

\subsection{Model selection}

Suitable substitution models for the datasets were determined using MrModeltest v2.3 [20] executed in PAUP* 4.0a152 [21] on the basis of Akaike Information Criterion (AIC). GTR+I+G model of nucleotide substitution was used for Dataset III in the present study.

\subsection{Tests for substitution saturation}

The following datasets were considered for the determination of substitution saturation using the entropy- 
Table 1 List of taxa utilized in the present study (including the taxa sequenced in the present study-marked by asterisk), taxonomic position, and accession numbers

\begin{tabular}{cll}
\hline Sr. no. & Taxon & Accession number \\
\hline Caenogastropoda & & \\
1 & Pila conica & EU274512 \\
Lower Heterobranchia &
\end{tabular}

\section{Orbitestellidae}

Orbitestella $s p$

EF561624

Acteonoidea

$3 \quad$ Rictaxis punctocaelatus

4

Pupa solidula

EF133484

EF133483

Pyramidelloidea

5 Turbonilla sp

EF133489

Architectibranchia

6

Micromelo undata

Opisthobranchia

Cephalaspidea

7

Haminoea hydatis

Aplysiomorpha

8

Akera bullata

Sacoglossa

9

Plakobranchus ocellatus

Umbraculoidea

10

Tylodina perversa

Nudipleura

Bathydoridoidea

$$
11
$$

$$
\text { Bathydoris clavigera }
$$

Anadoridoidea

$$
12
$$

Acanthodoris brunnea

13

Acanthodoris lutea

PULMONATA

Amphiboloidea$$
14
$$

Salinator solida

AF033712

Siphonarioidea - Siphonariidae

$\begin{array}{ll}15 & \text { Siphonaria concinna } \\ 16 & \text { Siphonaria denticulata }\end{array}$

Hygrophila

Chilinoidea

$\begin{array}{cc}17 & \text { Latia neritoides } \\ \text { Acroloxoidea } & \\ 18 & \text { Acroloxus lacustris } \\ \text { Lymnaeoidea } & \text { Lymnaeidae } \\ 19 & \text { Lymnaea acuminata* } \\ 20 & \text { Lymnaea stagnalis }\end{array}$

Planorboidea
Table 1 List of taxa utilized in the present study (including the

\begin{tabular}{|c|c|c|}
\hline Sr. no. & Taxon & Accession number \\
\hline \multicolumn{3}{|c|}{ Planorbidae } \\
\hline 21 & Gyraulus convexiusculus* & LC198673 \\
\hline 22 & Bulinus tropicus & HM756451 \\
\hline 23 & Bulinus obtusispira & HM756434 \\
\hline 24 & Indoplanorbis exustus & HM756427 \\
\hline 25 & Planorbarius corneus & HM756425 \\
\hline \multicolumn{3}{|c|}{ Physidae } \\
\hline 26 & Physa sp & HM756424 \\
\hline \multicolumn{3}{|c|}{ Eupulmonata } \\
\hline \multicolumn{3}{|c|}{ Otinoidea } \\
\hline 27 & Smeagol phillipensis & KM281155 \\
\hline \multicolumn{3}{|c|}{ Ellobiidae } \\
\hline 28 & Pedipes jouani & KM281135 \\
\hline 29 & Pedipes ovalis & KM281136 \\
\hline 30 & Carychium minimum & KC206193 \\
\hline 31 & Ophicardelus ornatus & AF033707 \\
\hline \multicolumn{3}{|c|}{ Systellommatophora } \\
\hline \multicolumn{3}{|c|}{ Onchidiidae } \\
\hline 32 & Onchidella celtica & KM281154 \\
\hline 33 & Onchidella floridiana & EF133485 \\
\hline 34 & Onchidella marginata & KF258015 \\
\hline 35 & Onchidella nigricans & KF258011 \\
\hline 36 & Onchidium sp. & AF033706 \\
\hline 37 & Onchidella borealis & KM281153 \\
\hline \multicolumn{3}{|c|}{ Veronicellidae } \\
\hline 38 & Veronicella cubensis & KC206240 \\
\hline 39 & Laevicaulis alte* & KX514448 \\
\hline \multicolumn{3}{|c|}{ Stylommatophora } \\
\hline \multicolumn{3}{|c|}{ Sigmurethra } \\
\hline \multicolumn{3}{|c|}{ Helicoidea; Helicidae } \\
\hline 40 & Arianta arbustorum & KF596915 \\
\hline 41 & Cepaea nemoralis & JX156675 \\
\hline 42 & Chilostoma ambrosi & $J X 156750$ \\
\hline \multicolumn{3}{|c|}{ Orthurethra } \\
\hline \multicolumn{3}{|c|}{ Pupilloidea; Orculidae } \\
\hline 43 & Orcula dolium & KC569278 \\
\hline 44 & Orcula gularis & KM188948 \\
\hline
\end{tabular}
taxa sequenced in the present study-marked by asterisk), taxonomic position, and accession numbers (Continued)

based test of Xia et al. [22] implemented in DAMBE v6.4.48 [23]. Apart from this, $p$-distances were plotted against the distance obtained under GTR model in DAMBE for determining the saturation of a given loci.

1. Dataset I. Original unmasked sequence alignment 
2. Dataset II. Sequence alignment refined by GBlocks under "more stringent" option

3. Dataset III. Sequence alignment refined by GBlocks under "less stringent" option

H3 gene was analyzed on the basis of its codonscodon 1 , codon 2 , codon 3 , codons $1 \& 2$ combined, and codons $1,2, \& 3$ combined.

In Dataset 3, codon 1, codon 2, codons 1, 2, \& 3 (combined), and codons $1 \& 2$ (combined) did not show saturation. For codon 3, only few taxa were saturated. Hence, the nucleotide sequences of codons 1, 2, \& 3 were combined (dataset III) and subsequently used for phylogenetic analyses in the present study. The dataset III consisted of 231 nucleotides.

Plots of $p$-distances against the evolutionary distances obtained under GTR model for codons 1, 2, \& 3 combined for all the three datasets showed saturation of transitions and showed similar pattern across all the three datasets. Similarly, for codons $1 \& 2$ combined for all the three datasets, transitions are saturated. Codon 3 of all the three datasets showed a high degree of substitution saturation for both the transitions and transversions.

\subsection{Phylogenetic analyses}

Bayesian inference (BI) of phylogeny (Fig. 1) and maximum likelihood (ML) analysis (Fig. 2) were carried out in MrBayes v3.2.5 [24] and raxmlGUI 1.5b2 [25] respectively under GTR $+\mathrm{I}+\mathrm{G}$ model.

ML analysis was carried out for 1000 bootstrap replications. Bayesian analysis was carried out for 10 million generations with two independent runs. Each run consisted of four chains (3 heated and 1 cold) with default heating parameters. Sampling was done at the end of every 1000th generation with $25 \%$ of the initial trees discarded as burnin. The average standard deviation of the split frequencies at the end of 10 million generations was 0.006199 . TRACER v1.6 [26] was used to determine the effective sample size (ESS) and it was found to be $>500$.

The phylograms were visualized by importing the ".con" and "bipartitions.tre" files from MrBayes and RAxML respectively into iTOL v3 - http://itol.embl.de/ [27]. Apart from iTOL (Fig. 2), TreeGraph 2.14.0-771 beta was also used for annotating the phylogenetic tree (Fig. 1) [28]. In the subsequent section, bootstrap and posterior probability values were represented either as $(1 / 100)$ which means a PP of 1 and a bootstrap value of 100 or in parenthesis next to the abbreviated form of the respective analysis or towards the end of a sentence discussing the same.

\section{Results}

\subsection{Topology of the phylogenetic trees}

ML tree (Fig. 2) was comparatively resolved than BI tree (Fig. 1). However, none of the deeper nodes in ML tree had bootstrap support compared to Bayesian tree. As a result, reliable inferences from ML tree could not be drawn regarding the overall relationships within Heterobranchia, except for a few bootstrap-supported external nodes. As a result, one should not consider the following conclusions inferred from the ML tree-paraphyly of Pulmonata, polyphyly of Opisthobranchia, and lower Heterobranchia.

From the topologies of the phylogenetic trees recovered in the present study, it was not possible to clearly assign the monophyly of lower Heterobranchia, Opisthobranchia, Pulmonata, and Euthyneura. The concept of Euthyneura seems to be non-existent as lower Heterobranchia was not basal in ML and BI trees.

\subsection{Lower Heterobranchia}

A total of five lower Heterobranch taxa were included in the present study.

Pupa solidula, Turbonilla sp, Rictaxis punctocaelatus, and Micromelo undata formed a monophyletic clade in BI (0.98) and ML (63) phylograms. This emerged as a sister clade to Lymnaeidae and Planorbidae with moderate support in BI (0.62). Acteonoidea recovered as nonmonophyletic in BI and ML trees.

Orbitestella $s p$ formed a monophyletic clade with an Opisthobranch Haminoea hydatis in both BI (0.99) and ML (56) analyses.

None of the lower Heterobranch taxa emerged basal in ML and BI phylograms.

\subsection{Opisthobranchia}

Of all the Opisthobranch taxa included in the present study, Acanthodoris sps formed a monophyletic clade. The relationships of the remaining Opisthobranch taxa were not clearly resolved.

Aplysiomorpha: Akera bullata formed a basal clade in BI and ML trees. In BI tree, it formed a monophyletic clade with the outgroup taxa Pila conica (Caenogastropoda).

Sacoglossa: Plakobranchus ocellatus was the next basal taxon in BI (0.71) and ML trees.

Cephalaspidea: Haminoea hydatis formed a monophyletic clade with a lower Heterobranch taxon in BI (0.99) and ML (56) trees.

\section{Nudipleura:}

Anadoridoidea: Acanthodoris brunnea and Acanthodoris lutea formed a monophyletic clade in BI (1) and ML (100) analyses and emerged as a sister clade to Ellobiidae.

Bathydoridoidea: Bathydoris clavigera formed a monophyletic clade with Tylodina perversa (Umbraculoidea Tylodinidae) in ML (56) tree.

\subsection{Pulmonata}

Siphonariidae: Siphonaria concinna and Siphonaria denticulata formed a monophyletic clade in BI (0.94) and ML analyses. 


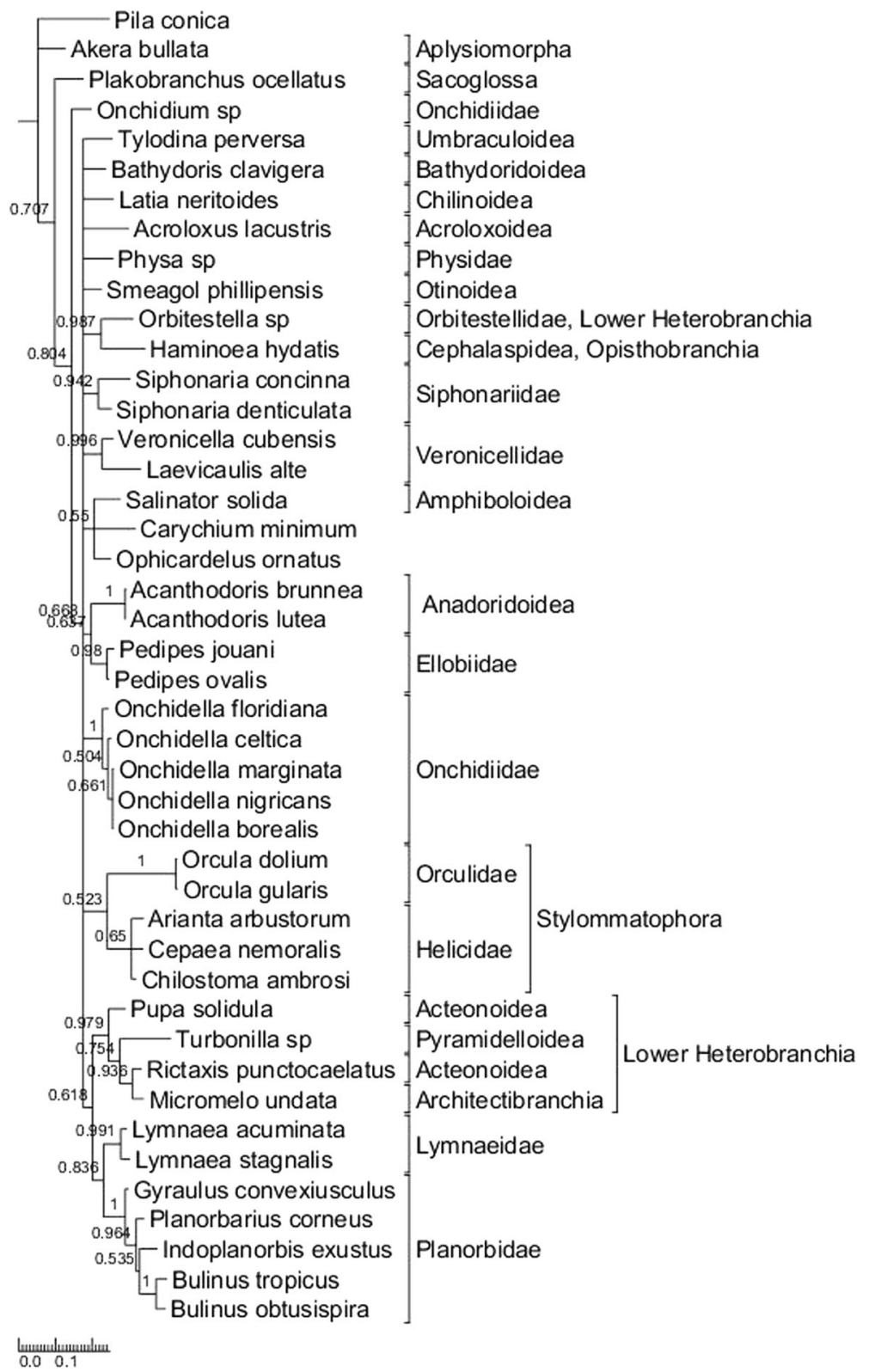

Aplysiomorpha

Sacoglossa

Onchidiidae

Umbraculoidea

Orbitestellidae, Lower Heterobranchia

Cephalaspidea, Opisthobranchia

Siphonariidae

Veronicellidae

Amphiboloidea

Anadoridoidea

Ellobiidae

Onchidiidae

Orculidae

Stylommatophora

Acteonoidea

Lower Heterobranchia

Fig. 1 Bayesian phylogram depicting the relationships among taxa on the basis of $\mathrm{H} 3$ (codons 1,2 \& 3 combined) gene. Indicated on the nodes are posterior probability (PP) values. Only PP values $>0.5$ are shown

\section{Hygrophila:}

Lymnaeidae: Two species viz., Lymnaea acuminata and Lymnaea stagnalis formed a monophyletic clade in $\mathrm{BI}$ and ML trees with strong node support values $(0.99 /$ 89).

Planorbidae: Planorbidae represented by five species formed a monophyletic clade with strong support both in BI (1) and ML (89) trees.

Lymnaeidae and Planorbidae in turn formed a monophyletic clade in BI (0.84) and ML trees. This clade emerged as a sister clade to Lower Heterobranchia.

Eupulmonata:
Ellobiidae: Of the four Ellobiids Pedipes jouani, Pedipes ovalis, Carychium minimum, and Ophicardelus ornatus included in the present study, Pedipes jouani and Pedipes ovalis formed a monophyletic clade in BI (0.98) and ML (82) phylograms. They emerged as a sister clade to Opisthobranch taxa Acanthodoris brunnea and Acanthodoris lutea in BI (0.64) and ML trees.

Carychium minimum, Ophicardelus ornatus, and Salinator solida (Amphiboloidea) together formed a monophyletic clade in BI (0.55) and ML trees. These two clades were differently positioned in the phylogenetic trees. 


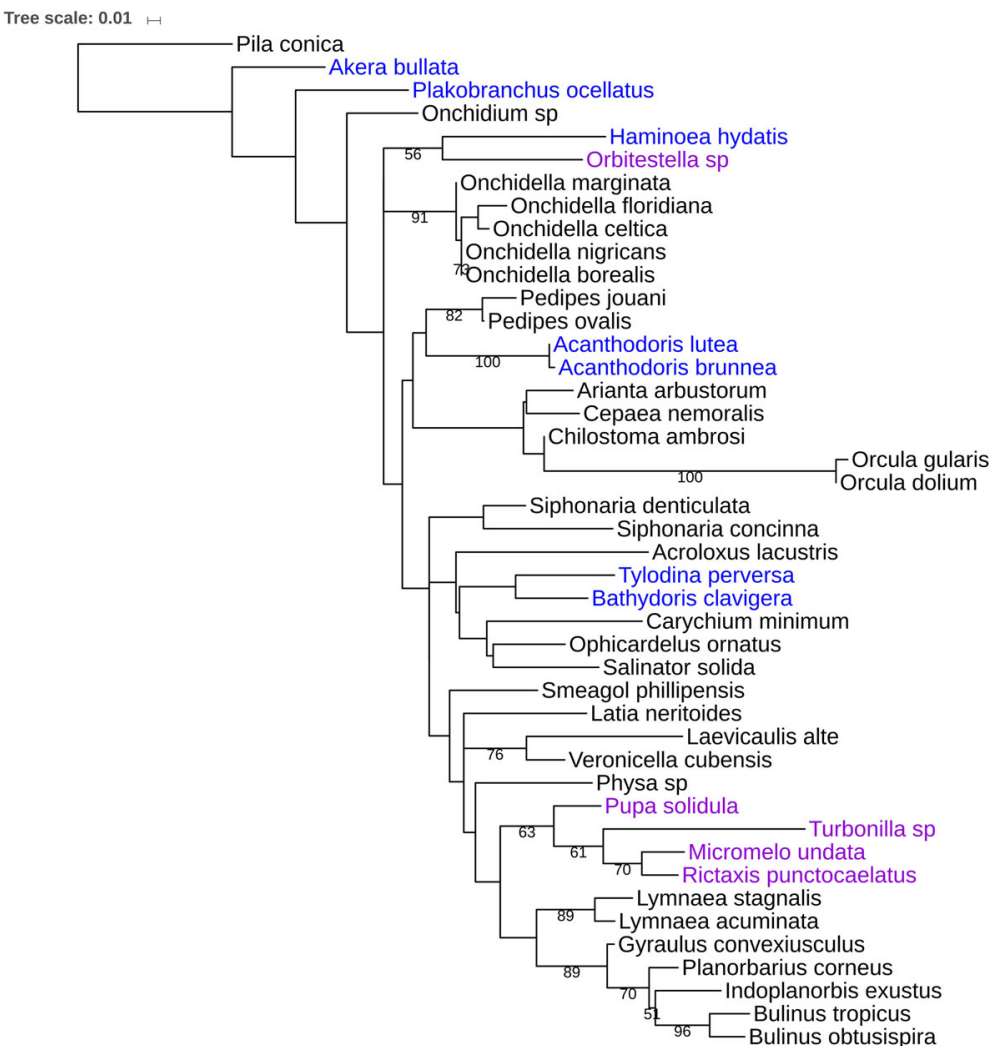

Fig. 2 Maximum likelihood phylogram depicting the relationships among taxa on the basis of H3 (codons 1, 2 \& 3 combined) gene. Indicated on the nodes are the bootstrap values. Tree scale of 0.01 represents 1 substitution per 100 nucleotides. Only bootstrap values $>50$ are shown

\section{Systellommatophora:}

Onchidiidae: Of the six Onchidiids included in the present study, Onchidium sp emerged as a basal taxon in both BI (0.80) and ML analyses. Remaining five taxa formed a monophyletic clade in BI (1) and ML (91) trees.

Veronicellidae: Laevicaulis alte and Veronicella cubensis formed a monophyletic clade in both BI (1) and ML (76) analyses.

Most importantly, Onchidiidae and Veronicellidae did not group together in BI and ML phylograms to form a monophyletic Systellommatophora. Each of the two families was positioned differently in ML and BI trees.

Stylommatophora: Stylommatophora recovered monophyletic in both BI (0.52) and ML analyses.

\section{Discussion}

In the present study, $\mathrm{H} 3$ sequence information was used to assess the phylogenetic relationships within Heterobranchia, in particular to Pulmonata. In the present study, H3 gene sequences of taxa belonging to major pulmonate groups' viz. Planorbidae, Ellobiidae, Onchidiidae, Veronicellidae, and Stylommatophora (represented by Helicidae and Orculidae) were retrieved from GenBank and included along with the sequences obtained in the present study for studying the phylogenetic relationships among pulmonates.

Relationships among Opisthobranchia, Lower Heterobranchia, and Pulmonata could not be determined from the topology of the trees recovered. ML tree is better resolved compared to Bayesian tree. However, none of the inner nodes were bootstrap supported. In ML and Bayesian trees, there was no step wise or progressive arrangement of taxa from Lower Heterobranchia to Pulmonata.

A few of the pulmonate groups' viz. Planorbidae, Veronicellidae, and Orculidae recovered monophyletic with node support in both BI and ML trees. Stylommatophora formed a monophyletic clade in both ML and BI trees with high node support seen only for BI tree. Systellommatophora is non-monophyletic. It is interesting to observe that Onchidium sp emerged as a basal taxon from the rest of the Onchidiids in ML and BI trees. This is similar to the results obtained in the study of Dinapoli et al. [12] where Onchidium $s p$ emerged separately from the remaining onchidiids.

The monophyly of Eupulmonata consisting of Systellommatophora and Stylommatophora and also the concept of Geophila [29] was not observed from the topologies of ML and BI trees as Stylommatophora and 
Systellommatophora were positioned differently in the phylograms. Taxa from Lower Heterobranchia emerged as a sister clade to Pulmonata and Opisthobranchia.

Further, the gene sequence information for $\mathrm{H} 3$ marker is not available for several taxa when compared to $16 \mathrm{~S}$, $18 \mathrm{~S}, 28 \mathrm{~S}$, and COI. A simple search in the international nucleotide databases (DDBJ, NCBI, and EMBL) shall reveal this fact. As an example, Systellommatophora consists of three families' viz. Onchidiidae under the superfamily Onchidioidea, Veronicellidae and Rathouisiidae under the superfamily Veronicelloidea. As at April 2019, there is only one sequence available for Veronicella cubensis belonging to the family Veronicellidae in NCBI GenBank. Hence, Veronicellidae is underrepresented and the nucleotide sequence of $\mathrm{H} 3$ gene obtained from the present study for Laevicaulis alte belonging to this family was reported for the first time. Similarly, there is only one Histone-3 gene sequence available for Lymnaea stagnalis under "Lymnaeoidea/ Lymnaeidae". In the present study, Lymnaea acuminata of this family was sequenced and this report is also the first of its kind.

Colgan et al. [14, 15] have utilized $\mathrm{H} 3$ gene in combination with other marker(s) for studying the phylogeny of Gastropoda. In their studies, pulmonates were poorly represented and consisted of only five pulmonates. Whereas, the present study included a large number of pulmonate taxa representing major groups in Pulmonata. In contrast to the results obtained in the present study, Euthyneura recovered monophyletic in these two studies. In the study of Colgan [14], within Euthyneura, opisthobranchs were paraphyletic with respect to pulmonates. When $\mathrm{H} 3$ gene alone was used, it resulted in an unresolved topology (polytomy). In the study of Colgan [15], Lower Heterobranchia ("Heterostropha") and Heterobranchia are rarely monophyletic and monophyly of Opisthobranchia could not be determined due to tree topologies. This is more or less similar to the results obtained in the present study, where Lower Heterobranchia and Opisthobranchia did not emerge monophyletic.

Dinapoli et al. [12] had utilized the $\mathrm{H} 3$ gene alone in reconstructing the phylogeny of Heterobranchia. Unlike the present study, her study consisted of only nine pulmonates and most of the pulmonate groups were not represented. The phylograms lacked resolution as a result of which the monophyly of Pulmonata and Opisthobranchia were not obtained. Similar to the results obtained in the study, there is a good resolution at the level of genera.

\section{Conclusion}

The present study, for the first time reported the phylogeny of Pulmonata with increased number of taxa on the basis of $\mathrm{H} 3$ gene. This is in contrast to most of the phylogenetic studies, which focused on few of the widely used markers viz. 16S, 18S, 28S, and COI. Further, in order to obtain accurate results on the phylogenetic relationships among Heterobranchia and in particular to Pulmonata, there is a need for the utility of new molecular markers like H3 gene; particularly to study the divergences of deep nodes. However, phylogenies on the basis of $\mathrm{H} 3$ gene lacked resolution owing to high grade of conservation and high codon usage bias that results in partially obscured phylogenetic signal [12]. In the present study, a few of the major groups in Pulmonata recovered monophyletic. In the future, sequencing more number of taxa for $\mathrm{H} 3$ gene from different groups of Pulmonata, with increased sequence lengths may shed deeper insights into the phylogeny of Pulmonata and Heterobranchia.

\section{Abbreviations}

Bl: Bayesian inference; ESS: Effective sample size; H3: Histone-3; ML: Maximum likelihood; NCBI: National Centre for Biotechnology Information

\section{Acknowledgements}

Authors acknowledge Drs. Tulika Biswas and Amit Kumar Mukhopadhyay from Zoological Survey of India, Kolkata, for identifying the gastropod specimens.

\section{Authors' contributions}

VSA conceived the study, carried out experiments, performed phylogenetic analyses, and was a major contributor in drafting the manuscript. KS obtained funding, drafted, and corrected the manuscript. All authors read and approved the final manuscript.

\section{Funding}

This work was funded by the Science and Engineering Research Board (SERB), Department of Science and Technology (DST), Government of India (Sanction order SB/SO/AS-138/2012 dated 30 October 2013) for carrying out experimental work and also the "Junior Research Fellowship" provided to the first author for carrying out the research work.

Availability of data and materials

Nucleotide sequences were deposited to GenBank and DDBJ and are available online. The rest of the data, if any, will be provided by authors upon request.

Ethics approval and consent to participate

Not Applicable

Consent for publication

Not Applicable

\section{Competing interests}

The authors declare that they have no competing interests.

Received: 1 July 2019 Accepted: 30 September 2019

Published online: 18 November 2019

References

1. Haszprunar G (1985) The Heterobranchia - a new concept of the phylogeny of the higher Gastropoda. J Zool Syst Evol 23:15-37

2. Haszprunar G, Huber G (1990) On the central nervous system of Smeagolidae and Rhodopidae, two families questionably allied with the Gymnomorpha (Gastropoda: Euthyneura). J Zool 220:185-199

3. Spengel JW (1881) Die Geruchsorgane und das Nervensystem der Mollusken. Zeitschrift für Wissenschaftliche 35:333-383

4. Dayrat B, Conrad M, Balayan S, White TR, Albrecht C, Golding R et al (2011) Phylogenetic relationships and evolution of pulmonate gastropods 
(Mollusca): new insights from increased taxon sampling. Mol Phylogenet Evol 59:425-437

5. Dinapoli A, Klussmann-Kolb A (2010) The long way to diversity - phylogeny and evolution of the Heterobranchia (Mollusca: Gastropoda). Mol Phylogenet Evol 55:60-76

6. Dinapoli A, Zinssmeister C, Klussmann-Kolb A (2011) New insights into the phylogeny of the Pyramidellidae (Gastropoda). J Molluscan Stud 77:1-7

7. Grande C, Templado J, Cervera JL, Zardoya R (2004) Molecular phylogeny of Euthyneura (Mollusca: Gastropoda). Mol Biol Evol 21:303-313

8. Grande C, Templado J, Zardoya R (2008) Evolution of gastropod mitochondrial genome arrangements. BMC Evol Biol 8:1-15

9. Klussmann-Kolb A, Dinapoli A, Kuhn K, Streit B, Albrecht C (2008) From sea to land and beyond- new insights into the evolution of Euthyneuran Gastropoda (Mollusca). BMC Evol Biol 8:1-16

10. Thollesson M (1999) Phylogenetic analysis of Euthyneura (Gastropoda) by means of the 16S rRNA gene: use of a fast gene for higher-level phylogenies. Proc R Soc Lond B Biol Sci 266:75-83

11. Maxson R, Cohn R, Kedes L (1983) Expression and organisation of histone genes. Annu Rev Genet 17:239-277

12. Dinapoli A, Tamer C, Franssen S, Naduvilezhath L, Klussmann-Kolb A (2006) Utility of H3-gene sequences for phylogenetic reconstruction - a case study of heterobranch Gastropoda. Bonn Zool Beitr 55:191-202

13. Colgan DJ, McLauchlan A, Wilson GDF, Livingston SP, Edgecombe GD, Macaranas J et al (1998) Histone H3 and U2 snRNA DNA sequences and arthropod molecular evolution. Aust J Zool 46:419-437

14. Colgan DJ, Ponder WF, Eggler PE (2000) Gastropod evolutionary rates and phylogenetic relationships assessed using partial $28 \mathrm{~S}$ rDNA and histone $\mathrm{H} 3$ sequences. Zool Scr 29:29-63

15. Colgan DJ, Ponder WF, Beacham E, Macaranas JM (2003) Gastropod phylogeny based on six segments from four genes representing coding or non-coding and mitochondrial or nuclear DNA. Molluscan Res 23:123-148

16. DNA Baser Sequence Assembler v4. 2013. Heracle BioSoft. www.DnaBaser. com/. Accessed June 2016

17. Tamura K, Stecher G, Peterson D, Filipski A, Kumar S (2013) MEGA6: molecular evolutionary genetics analysis version 6.0. Mol Biol Evol 30:2725-2729

18. Edgar RC (2004) MUSCLE: multiple sequence alignment with high accuracy and high throughput. Nucleic Acids Res 32:1792-1797

19. Castresana J (2000) Selection of conserved blocks from multiple alignments for their use in phylogenetic analyses. Mol Biol Evol 17:540-552

20. Nylander JAA (2004) MrModeltest v2.3 program distributed by the author. Evolutionary Biology Centre, Uppsala University

21. Swofford DL (2002) PAUP*. Phylogenetic analysis using parsimony (*and other methods). Version 4. Sinauer associates, Sunderland, Massachusetts

22. Xia X, Xie Z, Salemi M, Chen L, Wang Y (2003) An index of substitution saturation and its application. Mol Phylogenet Evol 26:1-7

23. Xia X (2013) DAMBE5: a comprehensive software package for data analysis in molecular biology and evolution. Mol Biol Evol 30:1720-1728

24. Ronquist F, Teslenko M, Van der Mark P, Ayres DL, Darling A, Höhna S et al (2012) MrBayes 3.2: efficient Bayesian phylogenetic inference and model choice across a large model space. Syst Biol 61:539-542

25. Silvestro D, Michalak I (2012) raxmlGUl: a graphical front-end for RAxML. Org Divers Evol 12:335-337

26. Rambaut, A., Suchard, M.A., Xie, W., Drummond, A.J., 2014. Tracer v1. 6. Available from: http://beast.bio.ed.ac.uk/Tracer/. Accessed May 2017

27. Letunic I, Bork P (2016) Interactive tree of life (iTOL) v3: an online tool for the display and annotation of phylogenetic and other trees. Nucleic Acids Res 44:W242-W245

28. Stöver BC, Müller KF (2010) TreeGraph 2: combining and visualizing evidence from different phylogenetic analyses. BMC Bioinformatics 11:7

29. Férussac JBL (1819) Histoire Naturelle des Pulmonés sans Opercules. ArthusGertrand, Paris

\section{Publisher's Note}

Springer Nature remains neutral with regard to jurisdictional claims in published maps and institutional affiliations.

\section{Submit your manuscript to a SpringerOpen ${ }^{\circ}$ journal and benefit from:}

- Convenient online submission

- Rigorous peer review

- Open access: articles freely available online

High visibility within the field

- Retaining the copyright to your article

Submit your next manuscript at $\boldsymbol{\nabla}$ springeropen.com 